\title{
Causes and Effects of Frequent and Unannounced Electricity Blackouts on the Operations of Micro and Small Scale Industries in Kumasi
}

\author{
Imoro Braimah \\ Department of Planning, Kwame Nkrumah University of Science and Technology \\ Kumasi, Ghana \\ E-mail: ibraimah2002@yahoo.com \\ Owusu Amponsah \\ Department of Planning, Kwame Nkrumah University of Science and Technology \\ Kumasi, Ghana \\ E-mail: amponsah_owusu@yahoo.co.uk
}

Received: December 1, 2011

Accepted: January 5, 2012 Published: February 1, 2012

doi:10.5539/jsd.v5n2p17

URL: http://dx.doi.org/10.5539/jsd.v5n2p17

\begin{abstract}
The aim of this paper was to examine the causes and effects of the frequent and unannounced electricity blackouts on the operations of micro and small scale industries (MSI) in Kumasi, Ghana. Data from a sample of 320 MSI selected from three industrial clusters in the Kumasi metropolis, revealed that the frequent and unannounced blackouts have caused a deficit of about $5.3 \%$ in the quantity of electricity they required for continuous operations. The blackout hours were estimated to last for an average of 10.3 hours per month. As a consequence of the blackouts, about $44 \%$ of the MSI spent this duration in redundancy because of lack of alternative sources of electricity but maintained the same labour cost. The remaining 56\% of the MSI obtained power from alternative sources which required an average of GHф15.5 per month to run. The paper concludes that uninterrupted electricity supply is vital for the effectiveness of the MSI.
\end{abstract}

Keywords: Frequent and unannounced blackouts, Electricity, Micro and small scale industries, Kumasi

\section{Introduction}

Micro and small scale industries (MSI) contribute significantly to employment creation, income and revenue generation, and overall poverty reduction in developing countries (Aremu \& Adeyemi, 2011; Mensah, 2004; NDPC, 2008). Kayanula and Quartey (2000) and NDPC (2003) add that the MSI sector plays kingpin roles in driving developing countries' engines of growth. The labour intensive nature of MSI is the explanation for the significant roles they play in national development (Albaladejo, 2000 cited in UN, 2006; Sullivan \& Steven, 2003). According to UNESCO (n.d.), MSI can promote rural development. This claim is made based on a small scale textile industry's contribution to the development of Dujaila (in Iraq). The textile industry was established by the Iraqi government in collaboration with the International Labour Organisation (ILO). The development of large corporations in developing countries is highly dependent on the presence of MSI. Rostow explains this in "the Process of Economic Growth" (1952 cited in Malerba and Orsenigo, 1994) and the "Stages of Economic Growth" (1960 cited in Malerba and Orsenigo, 1994). He argues that the dynamics of industries usually starts with a takeoff (small or medium scale but efficient) and then moves to technological maturity, usually associated with high mass consumption (large scale firms that employ high level of factors of production). In sum, MSI play significant roles in national development.

There is also a consensus among many experts that access to electricity relates positively to the development of the MSI sub-sector of national economies (AusAID, 2001; Oviemuno, 2006; Velázquez, 2006). In the view of Oviemuno (2006), the MSI sector is a major user of any country's stock of energy. Due to this, manufacturers always stress on the provision of affordable and reliable electricity for production. Similarly, Kahane and Squitieri (1987) reveal that the manufacturing sector of the United State's economy (which includes MSI) consumes 30\% (about 650 billion $\mathrm{kWh}$ per year) of the US total electricity production. Premised on the significance of MSI in national development and the subsequent contribution electricity makes in enhancing 
these roles, Ofosu-Ahenkorah (2008) argues that one of the vital factors for the sustenance of Ghana's middle-income status is the supply of reliable electricity to the MSI subsector. Thus, MSI's role in the attainment and sustenance of Ghana's middle income status could be enhanced with a reliable and adequate supply of electricity.

The Daily Graphic, one of Ghana's leading newspapers, reports that Ghana's middle income economic status will require about 5,000 Mega Watts (MW) of electricity to sustain itself (Daily Graphic, 2009). This underpins the Government's goal of increasing installed power generation capacity from about 2,000 MW to 5,000 MW by 2015 and subsequently becoming a net exporter of power (Ministry of Energy, 2010). Expanding electricity generation capacity to the 2015 target would facilitate the Government's aim of achieving universal access to electricity by 2020 from the current level of 66\% (Ministry of Energy, 2010). However, without augmented investments in the power sector, total electricity generation capacity will be only about 2,665 MW by 2015, leaving a deficit of about $46.7 \%$. The challenge is how to attract investments to build the necessary infrastructure for the generation, transmission and distribution of electricity throughout the country (Ministry of Energy, 2010).

Further limiting the ability to expand the electricity generation capacity is the hydro electric power (HEP) dominance in the national power generational-mix; accounting for about 58.4\% (Awotwi, 2011). HEP has not been reliable due to unfavourable rainfall regimes and increasing temperatures resulting from climate change. Gyau-Boakye and Tumbulto (2001) identified that climate change has reduced the volumes of the Volta Lakes' tributaries by more than $20 \%$. Their ccomparisons of runoffs for two time periods show reductions in mean stream flows of $32.5 \%$ at Saboba on the River Oti and $23.1 \%$ at Nawuni on the White Volta (Gyau-Boakye \& Tumbulto, 2000). Niasse (2005) also adds that West Africa's major rivers (Niger, Senegal and Volta) have experienced concomitant decrease in average discharge of between 40 to 60\%. The 1983/84, 1998 and 2007 erratic rainfall regimes which rendered the HEP dams ineffective with the subsequent power rationing exercises is the evidence in support of the glooming impact of climate change on HEP supply in Ghana. Compounding HEP's ineffectiveness is the increasing demand for electricity resulting from the ever-increasing number of consumers (Ministry of Energy, 2010).

Complementary power generated from thermal plants with the intent of augmenting electricity supply in Ghana has not provided an antidote to the inadequate and unreliable supplies of electricity (Institute of Statistical, Social and Economic Research (ISSER), 2005). ISSER (2005) and Kumasi Metropolitan Assembly (KMA, 2006) assert that increasing population with corresponding inelastic supply of electricity are the major factors affecting the reliable supply of electricity for industrialisation in Ghana. Compounding the problem is the inability of the Electricity Company of Ghana (ECG) to replace old transformers and loaders with new ones of higher capacities. This is blamed on unrealistic electricity tariffs (ESMAP, 2006). Electricity feeders and transformers have consequently been overloaded causing frequent and unannounced blackouts in Ghana. Due to this, industries ranked interrupted power supply highest among 13 other problems (NDPC, 2008; Association of Ghana Industries (AGI), 2009). It has been identified that the affected enterprises experience poor service quality which destroys machinery and goods and thus increase their production cost. The frequent and unannounced blackouts are not unique to Ghana as the Confederation of Tanzanian Industries (CTI) argues that Tanzania's manufacturing sector also experiences unreliable, intermittent power supply, frequent rationing and outages (CTI, 2011). The unreliable power supply causes manufacturers to experience throughout the year poor service quality, unplanned power stoppages and interruptions, voltage fluctuations, phase failures and unbalanced voltages (CTI, 2011).

Similarly, the economic cost of the 1977 New York City's blackout which lasted for about 25 hours was huge. The impact included; loss of production time, damage to plant equipment, destruction of product, and additional maintenance costs (Corwin \& Miles, 1977). It was estimated that the total direct and indirect economic cost of the blackout were US\$ 55.54 million and US\$ 290.16 million, respectively. Burlando (2010) also identified that a month-long blackout in Zanzibar in Tanzania caused a large decline in household income among those employed in occupations that required electricity. Workers relying on electricity had to reduce work hours by an average of $8 \%$ per day during the blackout period (Burlando, 2010). The August 14, 2003 blackout that occurred in New York, Michigan, Massachusetts, Ohio, New Jersey, Connecticut and Vermont all in the United States of America, caused an estimated loss of \$6.4 Billion (Anderson \& Geckil, 2003). The Centre for Policy Analysis (CEPA, 2007) identified that the 2007 power rationing exercise in Ghana resulted in increased local manufacturing costs. Available estimate indicate that the Government of Ghana lost about GH $\phi 14$ million in revenue as a result of a fall in production in various sectors including manufacturing, mining and quarrying. The lack of electricity for a significant portion of the day in Gaza severely disrupts the daily economic lives of Gaza Strip residents, very few of whom have the option of using generators (Kadman, 2009). Kadman further 
maintains that the long blackout period was a significant cause of the high unemployment levels and substandard social services (Kadman, 2009).

Vital as this information is to energy access planning, no attempts have been made to investigate the effects of intermittent power supply on the MSI who are in the majority and thus remain the bulk contributors to employment creation. Given the above context, this paper aims to examine the causes and effects of the frequent and unannounced blackouts on the operations of MSI in Kumasi, Ghana. The intent is to bridge the knowledge gap and with first hand information inform the nature of energy access programmes of action for MSI. This was achieved by analysing the issues that answer the following questions:

- What is the state of Ghana's electricity supply and demand especially in relation to the electricity needs of the MSI?

- What are the productive uses of electricity among the MSI?

- What are the causes of the frequent and unannounced blackouts in Ghana? Are the enterprises willing to pay higher tariffs?

- What are the effects of the frequent and unannounced blackouts on the operations of MSI in Kumasi?

- What coping strategies do the MSI use to limit the effects of the frequent blackouts in power supply? What are the cost implications of these coping strategies?

\section{Sources and Methods of Data Collection}

The researchers used information from both secondary and primary sources to assess the effects of the frequent and unannounced blackouts on the operations of MSI.

The secondary sources provided information on electricity supply efforts by successive governments in Ghana in the hope of supplying reliable and adequate electricity for industrialisation and other purposes. The primary data was gathered through direct interviews using structured questionnaires with seven purposively selected institutions and 320 sampled MSI as presented in Table 1. The seven institutions were; the Ministry of Energy (MOE), Volta River Authority (VRA), Electricity Company of Ghana (ECG), Energy Commission (EC), and Energy Foundation (EF). The others were the Public Utility Regulatory Commission (PURC) and Kumasi Institute of Technology and Environment (KITE). These institutions are in-charge of energy access plan preparation, implementation and monitoring and evaluation in Ghana. They were selected to give expert perspectives on the intermittency in power supply in Ghana which was used to triangulate the responses elicited from the enterprise owners. Sixteen apprentices randomly selected from the straightening and welding, and spraying firms were also interviewed through two focus group discussions (FGD).

The areas within the Kumasi Metropolis, where industrial operations are prominent, were clustered into three. The Suame Magazine Industrial Enclave, Sokoban Wood Village and the Central Business District (CBD) were the three industrial clusters. The stratified sampling technique was then applied to group the MSI into different strata based on the type of activity (i.e. nature of production) as indicated in Table 1. The strata were straightening and welding firms, spraying firms, printing presses, cold stores and wood processing firms. The rest were sachet water producing firms, dressmaking firms and grinding mills.

The straightening and welding, and spraying firms were selected from the Suame Magazine Industrial Enclave using the snowball sampling technique. The snowball sampling procedure was most appropriate due to the inability of the Magazine Mechanics Association to identify its members' exact location (address) within the enclave. With the snowball sampling technique, the first sprayer, and straighter and welder were identified through a reconnaissance survey. They were then asked to assist the researchers to identify the other sprayers and straighters and welders within the industrial enclave. On the other hand, the simple random sampling technique was used to select the cold stores, printing presses and grinding mills from the Kumasi Central Business District (CBD) and the wood processing firms from the Sokoban Wood Village based on master lists made available by the associations they belonged. Due to the proliferation of sachet water producing and dressmaking firms in the Kumasi metropolis, they were randomly sampled from across the metropolis guided by master lists provided by the Sachet Water Producers' Association and Dressmakers' Association. The specific simple random sampling technique adopted was the lottery method operationalised by assigning numbers to the enterprise owners on pieces of paper and placing them in a box. These numbers were then drawn one after the other, till the sample sizes were exhausted. 
The researchers adopted a formula from Brewer and Miller (2003) to determine the sample size at a $92 \%$ significant level for the enterprises, except the straighters and welders, and sprayers. The formula is stated and interpreted below.

$n=\frac{N}{1+N(\alpha)^{2}}$. Where $\mathrm{n}$ is the sample size (list of enterprise owners required to be interviewed); $\mathrm{N}$ is the sample frame (master list of enterprise owners) and $\alpha$ is the confidence interval (92\%). (See Table 1 for sample frames, required sample sizes and the actual number of enterprise owners interviewed.

The Suame Magazine Mechanics Association (MMA), the main mouthpiece of the industrialists within the Suame Magazine Industrial Enclave, could not provide a master list of the straighters and welders, and sprayers who were members of the association. This constrained the study in its determination of a sample size; hence the number interviewed was by intuition. The researchers used direct interface to elicit the required responses from the owners of the firms and this accounted for the $100 \%$ response rate as indicated in Table 1.

The effects of the intermittent power supply on the operations of the MSI were both quantitatively and qualitatively assessed. The quantitative analysis involved the estimation of the actual electricity needs of the MSI and the cost implications of obtaining electricity supply from other sources during blackout hours. The analysis estimated the amount of electricity the MSI consumed per hour which premised the determination of the amounts of electricity they would have consumed during the blackout periods. The hourly rate of consumption was estimated by dividing the total Kilowatt hours $(\mathrm{KWh})$ of electricity consumed by an enterprise per month by the number of hours it used electricity. This was considered as the potential electricity demand by the enterprise for a month. The difference between the potential and the actual demand (as recorded on their electricity bills) became the deficit. The difference is as a result of the frequent and unannounced blackouts.

The qualitative analysis also involved comprehensive statements from the stakeholders (enterprise owners and employees') which centred on the perceived effects of the frequent and unannounced blackouts on their operations which were determined through interviews with the stakeholders. The perceptions were triangulated with experiences of MSI in other countries from intermittent power supply. The researchers also examined the coping strategies adopted by the MSI during the blackout periods and their implications for their operations.

\section{Profile of the Industrial Clusters}

In this section of the paper, the researchers provide a synoptic description of the three industrial outlets viz. Suame Magazine, the Sokoban Wood Village (erstwhile Anloga Wood industry) and the Kumasi CBD, which were used as the study areas.

\subsection{The Suame Magazine Industrial Cluster}

Suame industrial cluster, famously known as 'Suame Magazine', once housed a military magazine (Adeya, 2006). Suame Magazine industrial enclave emerged in the 1950s when the entrepreneurs, who were formerly located in the CBD, were relocated to this current place of occupation (i.e. Suame Magazine) in the 1950s and 1960s (Adeya, 2006). Prior to their relocation, industries had started emerging at the former armouries in Kumasi as early as 1935 (Adeya, 2006).

The key turning point in the development of the MSI operating within the enclave was in the mid-1970s when Ghana introduced tight restrictions on the importation of new vehicles and spare parts (Dawson, 1988 cited in Adeya, 2006). This led to shortage of spare-parts in Ghana. The MSI sector, therefore, emerged to fill the gap as it was able to produce the previously imported spare-parts. Though in the 1980s, under the Structural Adjustment Programme (SAP), the importation of spare parts and vehicles resumed with the implementation of the trade liberalisation policy, the large scale enterprises did not regain their previous dominance. Since then, the MSI subsector has been growing rapidly in the metropolis. By the late 1990s, about 80,000 workers, operating in about 16,000 firms, had located and were operating within the industrial enclave (Obeng, 2000 cited in Adeya, 2006).

The enterprise owners and the workers in the Suame Magazine industrial enclave work in associations namely the Suame Magazine Garages Association and the Magazine Mechanic Association. The industrialists include sprayers, straighters and welders, vulcanisers, electricians, heavy and light duty mechanics, blacksmiths, etc.

\subsection{The Sokoban Wood Village}

The Sokoban Wood Village is inhabited by the resettled wood workers from the erstwhile Anloga Wood Industry. Their relocation was necessary to pave way for the construction of the Anloga-Asokwa bypass within the Kumasi Metropolis. The Wood Village is inhabited by about 4,000 wood processors who supply all the wood products (such as logs) required by carpenters and other consumers within and around the Kumasi metropolis (Amponsah, 2010). 


\subsection{The Kumasi Central Business District (CBD)}

Unlike the Suame Magazine Industrial Enclave and the Sokoban Wood Village which accommodate entrepreneurs with similar methods of production and products, the CBD is inhabited by different types of enterprises that produce different products. Their operations are believed to have limited environmental consequences hence their permission to locate within the core of the city. The MSI selected from the CBD were the grinding mills at the race course and central markets, printing presses at Adum, and cold stores operators at Asafo and the Kumasi Central Market. The enterprises were in clusters and were thus easily identified. The sachet water producers and dressmakers were selected from across the Metropolis because they were not clustered at any location.

All the enterprises selected from the three industrial clusters compete with other consumers for $120 \mathrm{MW}$ of electricity supplied by ECG in the Kumasi Metropolis every month. Electricity in the Metropolis is supplied through five bulk points with $231 \mathrm{~km}$ of overhead lines and 140.6km underground cables (KMA, 2010).

\section{Cause of the Frequent and Unannounced Blackouts in Ghana}

This section begins with a review of the interventions that have been made by successive governments to generate adequate and reliable electricity to enhance industrialisation in Ghana. Following this, there is an analysis of the amount of electricity consumed in relation to the total electricity generation capacity. The analysis of the electricity supply and demand situation offers an explanation for the frequent and unannounced blackouts in Ghana.

\subsection{Ghana's Total Installed Electricity Generation Capacity and Demand}

According to ISSER (2005), Ghana's current electricity system has evolved through three stages identified as 'the Before Akosombo', 'the Hydro-Years' and 'the Thermal Complementation' period.

The Before Akosombo category is the period preceding the first HEP project in Ghana (i.e. the years before 1966). During that time, diesel generators provided electricity to run Ghana's railway system. Electricity supplied from the diesel generators was extended to Accra and Koforidua in 1922 and 1926 respectively (ISSER, 2005). By 1955, towns like Cape Coast, Tema, Bolgatanga, Tamale, Kumasi, Nsawam, Dunkwa and Oda had been connected to the electricity grid from three major power stations established at Cape Coast in 1932, Swedru in 1948 and Keta in 1955 (ISSER, 2005). Power generated from the diesel plants during this period was not only expensive but also insufficient to facilitate Ghana's industrialisation agenda after independence (Amponsah, 2010; ESMAP, 2006).

The Hydro-years came about as a result of insufficient power supplied during 'the Before Akosombo' years for industrial purposes (i.e. supply to the Volta Aluminium Company - VALCO - to exploit Ghana's bauxite reserves) and other purposes (viz. administrative, health, educational and domestic uses). The Akosombo dam was subsequently constructed to provide industries and other consumers with a reliable and cost effective source of power (ISSER, 2005). According to Turkson and Amadu (1999) as of 1972, the Akosombo dam could generate 912 MW of electricity. By the end of 1975, the total installed power generation capacity in Ghana had risen to 1,072 MW mainly due to the construction of the Kpong dam (Turkson \& Amadu, 1999).

Edjekumhene, Atokora, Atta-Konadu and Brew-Hammond (2001) revealed that in 1983/84 there was a severe drought which reduced the water level in the Akosombo reservoir below the minimum operational level of 278 feet. The drought led to a $50 \%$ cut in electricity exports to Togo and Benin and a $95 \%$ cut in electricity supply to VALCO. This shortage led to 'thermal complementation' where electricity is supplied from thermal plants to complement HEP. The major thermal plants are located in Takoradi and Tema generating $550 \mathrm{MW}$ and $110 \mathrm{MW}$ of electricity, respectively (Awotwi, 2011). The other installed electricity generation point is the mines reserve plant $(80 \mathrm{MW})$ which produces 18 giggawatt hours (GWh). In all, VRA's total installed capacity is 1,930 MW (equivalent to about $8,957 \mathrm{GWh}$ ) as presented in Table 2. An additional $400 \mathrm{MW}$ project capable of generating about $1000 \mathrm{GWh}$ of electricity is under construction at Bui in the Brong Ahafo Region.

The analysis of the total installed capacity and total electricity demand reveals a supply deficit of about 9 GWh. Table 3 indicates that the total electricity demand as of 2008 was $8,450 \mathrm{GWh}$ and was estimated to increase to $8,966 \mathrm{GWh}$ in 2009. However, the total installed generational capacity as of 2009 was 8,957GWh (in Table 2). With the Government of Ghana's objective of attaining a universal access to electricity by 2020 and encouraging the switch from biomass to electricity and LPG as cooking fuels (Government of Ghana, 2005), the Energy Commission (2010) predicts a potential supply shortfall of more than/equal to 2,700 $\mathrm{GWh}$. In a similar vein, the Ghana Grid Company (GridCo) cited by the Energy Commission (2010) estimates the potential power shortfall to be $316 \mathrm{GWh}$ as presented in Table 3. With supply constraints, growth in demand for electricity is currently 
estimated at 10\% per annum (Ministry of Energy, 2010). This implies that Ghana requires capacity additions of about $200 \mathrm{MW}$ to catch up with increasing demand in the medium term (Ministry of Energy, 2010).

The Ghana National Commission for UNESCO (n.d.) also estimates the rate of growth in the demand for electric power in Ghana at $7 \%$. However, there is no corresponding increase in the power generation capacity which has resulted in a tight demand-supply balance with limited reserve margin, leading to periodic blackouts throughout the country.

The mismatch between demand and supply with the continuous widening gap between supply of and demand for electricity (due to the continuous connections of consumers to the national electricity grid) has resulted in intermittent power supply.

\subsection{Other Causes of the Frequent and Unannounced Blackouts}

The Kumasi Metropolitan Assembly (2006) claims that the high demand for electricity (the result of rapid urbanisation) coupled with the limited capacity of the utility companies to replace the transformers and loaders, are the causes of transformer overloads in the Metropolis. In 2006, $120 \mathrm{MW}$ of electricity was supplied to consumers in the Kumasi Metropolis. In 2010, the same quantity of electricity was supplied (KMA, 2010). However, the population of the Metropolis has been growing by about $5.4 \%$ implying an increasing demand for electricity. The ECG's inability to promptly replace transformers and loaders is partly the result of failure of institutions and households to settle their electricity bills (ECG, 2010). It is estimated that the total debt owed to ECG in 2010 was over GH\& 400 million (ECG, 2011). Transformer overloads coupled with the inelastic expansion of electricity generation sources are thus the causes of the frequent and unannounced blackouts in the Metropolis.

The causes of poor electricity service delivery tally well with the Tanzanian experience. In Tanzania, poor electricity service quality, unannounced power cuts, unplanned power stoppages and interruptions, voltage fluctuations, phase failures and unbalanced voltages are known to be caused by worn out power infrastructure (both for production and distribution of electricity); shortages in electricity production, and overdependence on HEP which is prone to the vagaries of the weather (notably drought) (Confederation of Tanzanian Industries, 2011).

The Ghana National Commission for UNESCO (n.d.) adds that the power supply interruptions occur due to the inadequate generation reserve margin, excessive transmission network constraints and poor voltage support.

\section{The Effects of the Frequent and Unannounced Blackouts on the MSI Operations}

This section of the paper discusses the effects of the frequent and unannounced blackouts on the operations of MSI in the Metropolis. The discussion is preceded by an identification of the productive uses of electricity among the MSI in Kumasi in order to help identify what economic activities are affected by the frequent unannounced blackouts.

\subsection{Productive Uses of Electricity Usage by the MSI}

The authors identified that the MSI located within and outside the selected industrial clusters in the Kumasi metropolis depended on electricity from the Electricity Company of Ghana (ECG) for their operations. Straightening and welding firms used electricity to straighten and weld cars and other metals into desirable forms. Vehicles which were involved in accidents within and outside the metropolis were taken to the Suame Magazine Industrial Enclave for repairs. Besides fixing accident damaged vehicles, the straighters and welders manufactured metallic gates, canopies, scaffolds and anti-burglary devices. The products from the straightening and welding firms were forwarded to sprayers as intermediate commodities to be sprayed or coated to prevent rusting and for beautification. The sprayers also sprayed automobiles. Similarly, the wood processors used electricity to operate their machinery (planes, mortises, saws, etc) to cut, saw, split, plane, tread and mortise logs into usable forms for the manufacture of furniture, beams, boards and planks. The processed logs from the wood processors were used as inputs by carpenters for the manufacture of wood furnishings including beds, wardrobes and other furniture, and for roofing buildings in and outside the metropolis.

The sachet water producers used electricity for the production of sachet water by cutting and sealing their polythene bags. The dressmakers also used electricity to sew clothes and bags. Cold stores used electricity for the preservation of fish and meat in their refrigerators. Grinding millers used electricity to drive their mills to process corn, cassava, 'kenkey', flour and vegetables into semi-finished products. Lastly, the printing presses used electricity to power their computers, photocopiers and printers to print pamphlets, posters, newspapers and books. 


\subsection{Quantity of Electricity Consumed and Tariffs Paid by the MSI}

Ghana's electricity tariff structure depicts a four-tier band which is tied to the amount (measured in KWh) of electricity consumed. Consumers who are within the first category (also known as the "lifeline tariff band") use not more than $50 \mathrm{KWh}$ of electricity per month. The second category of consumers (i.e. the residential band), use between 50-300 KWh of electricity per month. In the third and fourth categories, electricity consumption levels are between $301-600 \mathrm{KWh}$, and $601 \mathrm{KWh}$ and above, respectively (Ghanaweb, 1/06/2010). Subsequently, consumers within the lifeline tariff band, residential, third and fourth categories paid 9.5 Ghana Pesewas (Gp), 12Gp, 16Gp and 19Gp per KWh respectively as of May, 2010.

The tariff system also enjoined electricity consumers to pay 4Gp and 2Gp as Government service levy and street light levy respectively. Other charges were service charges of GH $\phi 2.5$, and Value Added Tax (VAT) and National Health Insurance Levy (NHIL) which constituted 15\% of the total amounts paid by non-residential users of electricity (consumption of more than $300 \mathrm{KWh}$ per month). In sum, the $\mathrm{KWh}$ cost of electricity increased with the consumption level.

In view of this, the cold stores which were identified as the highest consumers of electricity paid an average of GH $\not 174.8$ for using about $936.5 \mathrm{KWh}$ of electricity per month (see Table 4 and Appendix 1). The dressmakers who used the least amount of electricity (averaging $247.3 \mathrm{KWh}$ ) paid an average of GH $\notin 30.2$ per month. The mean quantities of electricity consumed by the enterprises were determined through the arithmetic mean approach by dividing the quantities of electricity the enterprises consumed per month by the number of enterprises in a category (See Appendix 1 for details of the calculations).

As a strategy to make electricity affordable to consumers, there is a $40 \%$ subsidy on the first $300 \mathrm{KWh}$ of electricity used by consumers within the second, third and fourth consumption categories (Ardayfio-Schandorf, 2009). Thus, firms that consumed between 51 and $300 \mathrm{KWh}$ paid $7.2 \mathrm{Gp}$ (instead of $12 \mathrm{Gp}$ ) for one $\mathrm{KWh}$ of electricity within the first $300 \mathrm{KWh}$ consumed per month. Similarly, firms which consumed between 301 and $600 \mathrm{KWh}$ paid $9.6 \mathrm{Gp}$ (instead of $16 \mathrm{Gp}$ ) per $\mathrm{KWh}$ for the first $300 \mathrm{KWh}$ of electricity they consumed. Furthermore, the firms which consumed more than $600 \mathrm{KWh}$ of electricity paid $11.4 \mathrm{Gp}$ (instead of $19 \mathrm{Gp}$ ) per a unit consumed within the first $300 \mathrm{KWh}$. The researchers identified that the government's subsidy on electricity has reduced MSI electricity tariffs by $18.8 \%$ (see Table 4 ).

\subsection{The Enterprises' Perception of the Electricity Tariffs}

Two thoughts are expressed by stakeholders within the electricity industry in Ghana about strategies required to improve electricity supply. The first thought, often opined by utility companies and the Ministry of Finance and Economic Planning (MoFEP), emphasises tariff reforms as a means to improving service delivery. They asserted that tariffs were too low and must be increased due to the mounting costs electricity generation from increased reliance on more expensive thermal generation, which is affected by continuous changes in oil prices (ESMAP, 2006). Through tariff increases, the utility companies would be better resourced to replace worn-out transformers and loaders for improved service delivery. The other school of thought led by consumers believe that a good justification for tariff increases is improved service delivery. They further maintain that the Government, through overall taxes or other sources, should bear a greater burden of the cost of service provision (ESMAP, 2005).

This paper seeks to enrich the debate with information on the perceptions of MSI on the current tariffs they pay. The aim is to predict consumers' reaction to any future increases in tariffs for an assessment of tariff increases as an option for improvement in electricity service delivery in Ghana.

Using a three-interval likert scale (viz. expensive, moderate and cheap) to examine the enterprise owners' perception of the monthly electricity tariffs they paid, the researchers identified that about $55 \%$ of them considered the electricity tariffs as expensive. All the cold store owners considered the tariffs as expensive as indicated in Figure 1. Additionally, about $20.5 \%$ of the dressmakers, $37.1 \%$ of the grinding millers, $66.7 \%$ of the printing press operators and $47.4 \%$ of the sachet water producing firms considered the tariffs they paid as expensive. Furthermore, $77.8 \%, 33.3 \%$ and $51.5 \%$ of the straightening and welding, spraying and wood processing firms respectively, considered the tariffs they paid as expensive. On the other hand, about $71.8 \%$, $62.9 \%, 33.3 \%$ and $52.6 \%$ of the dressmakers, grinding millers, printing presses and sachet water producing firms respectively, considered the tariffs they paid as moderate as indicated in Figure 1. Similarly, 22.2\%, 66.7\% and $48.5 \%$ of the straighters and welders, sprayers and wood processors, respectively considered the tariffs they paid as moderate. A further probe revealed that none of the entrepreneurs, except $7.7 \%$ of the dressmakers, perceived the tariffs they paid as cheap. The apprentices' views on the electricity tariffs were considered immaterial since they had no stake in the determination of how factors of production were combined in the enterprises. 
A cross-tabulation between the electricity tariffs paid by the entrepreneurs and their perceptions about the tariffs revealed that the enterprise owners' perceptions about the tariffs were influenced by the amount of electricity they consumed. Thus, the higher the quantity of electricity they consumed, the more expensive the entrepreneurs perceived the tariffs to be. As indicated in Appendix 2, about $78 \%$ of the straighters and welders, and all the cold store operators perceived the tariffs as expensive because they paid a minimum of $16 \mathrm{Gp}$ for a $\mathrm{KWh} / \mathrm{unit}$ of electricity they consumed. Similarly, $37 \%$ of the grinding millers and $33 \%$ of the sprayers who consumed more than $300 \mathrm{KWh}$ of electricity per month considered the tariffs as expensive.

Some exceptions were observed with sachet water producers and wood processors where about $53 \%$ and $39 \%$, respectively consumed between 300 and $600 \mathrm{KWh}$ of electricity but considered the tariffs as moderate. Nevertheless, the majority of the sachet water producers (i.e. $28 \%$ out of a proportion of $47 \%$ ) and all the wood processors who considered the tariffs as expensive consumed more than $600 \mathrm{KWh}$ of electricity. In a similar vein, about $63 \%$ out of the number of printing press owners who considered the tariffs as expensive consumed more than $600 \mathrm{KWh}$ and thus paid $19 \mathrm{Gp}$ per unit of electricity consumed.

Despite the widely-held perception that the electricity tariffs paid are expensive, the utility companies and regulators maintain that electricity tariffs paid by consumers in Ghana are unrealistic claiming that the tariffs are low (Afronews, 2010). A comparative analysis made with the electricity tariffs in the neighbouring countries of Cote d'Ivoire, Togo and Burkina Faso revealed that the cost of electricity is low in Ghana (ESMAP, 2005). A 2004 cross-country electricity tariff comparison revealed a KWh cost of 7.2 U.S cents in Ghana, 12.4 U.S cents in Benin, 10.7 U.S cents in Togo and 14.9 U.S cents in Burkina Faso (Afful-Dadzie, 2009). The undervaluation of electricity prices in Ghana is partly attributed to Government's direct control to prevent utility companies from charging beyond the means of many Ghanaians (ESMAP, 2005; Ghana Web, 2010).

Premised on the widely-held perception that Ghana's electricity tariffs are expensive though low tariffs are charged, any attempt to increase the tariffs may be met with ill-reactions. This claim is supported by the reactions that followed the PURC's announcement of an $89 \%$ increase in electricity tariffs in May, 2010. The announcement triggered agitations from civil society organisations and economic unions (such as the Alliance for Accountable Governance, Industrial and Commercial Workers Union, Association of Ghana Industries and the Trade Union Congress) which forced a downward review of the tariffs (myjoyonline News, July, 2010).

\subsection{Estimating the MSI Actual Electricity Demand and Supply}

Due to the frequent blackouts, the current level of electricity consumption of the MSI is not sufficient to maintain uninterrupted operations. Premised on this, the researchers estimated the hourly electricity consumption (in KWh) and thus were able to determine the quantity of electricity that would have been utilised by the firms during the blackout hours.

The researchers identified that all the firms required constant supply of electricity for uninterrupted operations. The cold stores required 168 hours per week ( 24 hours constant supply of electricity every day). The researchers used 24 hours as the basis for the estimation of the number of hours of constant electricity due to non-functioning thermostats in all the refrigerators surveyed and the fact that the refrigerators were kept on throughout a 24 hour period. The thermostat stops power to the compressor when the temperature drops below the desired setting. Thus, refrigerators with functional thermostats ensure energy efficiency.

Though the other enterprises required a constant supply of electricity, they needed it only during the working hours (in the daytime). The weekly hours of electricity the grinding millers and wood processors required were estimated to be 70 hours (10 hours for seven working days in a week) and 60 hours (10 hours for six working days in a week), respectively. The printing presses, straightening and welding firms, spraying firms, sachet water producing firms and dressmaking firms required 46.2 hours (i.e. 7.7 hours each day for six working days in a week), 36 hours (i.e. six hours of constant power supply for six working days in a week), 33 hours (i.e. 5.5 hours for six working days in a week), 37.2 hours (i.e. 6.2 hours for six working days in a week) and 32.4 hours (i.e. 5.4 hours for six working days in a week), respectively. The cold stores and grinding mills each used an average of $1.3 \mathrm{KWh}$ while the printing presses consumed $3.7 \mathrm{KWh}$ of electricity every hour as depicted in Table 5.

Despite the firms' need for constant electricity supply, they were affected by unannounced blackouts which lasted for an average of 10.3 hours per month (see Table 6). The straightening and welding, and spraying firms experienced about 12 blackout hours per month. The wood processing and dressmaking enterprises experienced the least blackout hours averaging 8 hours per month. The grinding mills, printing presses, cold stores and sachet water producing firms experienced 12,10,10.8 and 10.4 blackout hours respectively per month (Refer to Table $6)$. 
Following the identification of the hourly electricity consumption (in Table 5) and the mean monthly blackout hours, the researchers estimated the electricity needed by the enterprises for uninterrupted operations. Table 7 indicates that the monthly amounts of electricity required by the MSI (i.e. without any blackout) ranged from 261.7 KWh for the dressmaking firms to $950.5 \mathrm{KWh}$ for the cold stores. Hence, the frequent blackouts have reduced the amount of electricity required by the enterprises by about $5.3 \%$ (i.e. $25.3 \mathrm{KWh}$ per month).

\subsection{Effects of Interrupted Power Supply on the Operations of MSI}

The assessment of the impact of blackouts on the operations of MSI was limited by the poor record keeping behaviour of the entrepreneurs which King (2010) maintains is an attribute of the small scale informal economy of Ghana. The researchers thus analysed the effects of the intermittent power supply based on the enterprise owners' perception as well as by considering the coping strategies adopted by the enterprise owners and the cost implications.

All the entrepreneurs interviewed perceived the immediate effects of the frequent and unannounced blackouts to be the destruction of their equipment. The motors of the cold stores, grinding mills and wood processing firms were believed to be the most affected components of the machinery. About $32 \%$ of the cold store operators indicated that they replaced the motors of their refrigerators every year until they acquired stabilisers to control the intermittent power supply. They added that the frequent and unannounced blackouts destroyed their products (meat and fish) until they acquired standby sources of power (see Table 8). Similar effects of the frequent blackouts are reported in Asia where refrigerators are destroyed and food spoiled (Peters, Kesavan \& Palmer, n. d.).

About $28 \%$ and $15 \%$ of the wood processors had repaired their machinery once and twice during data collection in May, 2009. The affected wood processors argued that the frequent machinery breakdowns were the results of the frequent and unannounced blackouts in the Enclave. A wood processor said: "I was sawing wood when there was a blackout. When power was restored about one hour later, the electric saw I was using before the outage failed to respond. I am convinced that the fault was caused by the blackout and nothing else".

The enterprise owner's suspicion (expressed in the above quotation) is in tandem with the damage caused to manufacturers' machinery due to fluctuations in power supply in Tanzania and Nigeria (Confederation of Tanzanian Industries, 2010; Iwayemi, 2008). Similarly, Corwin and Miles (1978) identified destruction of plant and equipment as one of the numerous economic effects of the 1977 New York City blackout.

All the straightening and welding firms also complained of their inability to meet contract deadlines as a result of frequent and unannounced blackouts. A welder said: "My inability to meet contract deadlines is most pronounced in thunderous rainy days when power supply will cut automatically. If this lasts for a long time, I am unable to work throughout the period."

The enterprise owners' inability to meet contract deadlines due to the frequent and unannounced blackouts tallied well with the experiences of enterprise owners in Zanzibar who were compelled to reduce their working hours by about $8 \%$ due to a month-long frequent blackout (Burlando, 2010).

Apprentices in the straightening and welding, and spraying firms intimated that their trainers were unable to give them money for lunch and transport in days where long blackout hours prevented them from executing contracts. Thus not only is the economy loosing current income, but the education of future skilled workers is being impacted by the frequent blackouts which are often unannounced. Furthermore, the wood processors, dressmakers and sprayers complained that they were unable to meet contract deadlines during periods of excessive interruptions in the power supply.

Due to the frequent blackouts, all the cold store and printing press operators, and about $66.7 \%$ of the sachet water producers, and $22.4 \%$ of the dressmakers have acquired generators as standby sources of power (see Table 8). Subsequently, the cold store operators, printing press operators, sachet water producers and dressmakers used an average of 14.8, 16.6, 12.2 and 9.5 litres of petrol respectively per month in their backup generators. The cost of running these alternatives was estimated at $\mathrm{GH} \phi 16.5$, GH $\phi 18.5$, GH $\phi 13.5$ and $\mathrm{GH} \phi 10.5$ for the sachet water producers, cold store operators, printing press operators and dressmakers respectively.

Table 8 indicates that all the wood processors and grinding millers depended solely on electricity supplied by ECG. Similarly, $44.4 \%, 29.8 \%$ and $77.6 \%$ of straighters and welders, sachet water producers and dressmakers had no other alternative source of electricity and were consequently rendered redundant by blackout, averaging 10.3 hours per month. The grinding millers, wood processors, dressmakers and sprayers disclosed that the blackouts increase their cost of production. For example, with halt in production due to power outage, labour costs (measured in terms of wages) increase the cost of production since they are paid for no work done during 
these periods. In sum, the frequent blackouts experienced by the MSI in Kumasi increased their cost of production and affected their effectiveness in meeting contract deadlines.

\section{Summary, Recommendations and Conclusion}

The paper sought to examine the causes and effects of the frequent and unannounced blackouts on the operations of MSI in Kumasi. The researchers sampled and interviewed 320 MSI from three industrial clusters within the Kumasi metropolis, seven institutions and two groups of apprentices. The survey results affirmed the claim that electricity plays a pivotal role in the operations of MSI in the Kumasi metropolis. The study identified that MSI required constant supplies of electricity for their operations. For instance, the study revealed that the cold stores, grinding mills, wood processing firms and printing presses required about 168, 70, 60 and 46.2 hours, respectively of constant supply of electricity per week. The straightening and welding firms required 36 hours, spraying firms, 33 hours, sachet water producing firms, 37.2 hours and dressmaking firms, 32.4 hours of constant supply of electricity per every week for their operations.

However, electricity supply in Ghana has lagged behind demand. The supply deficit is the result of the ever increasing consuming population. An analysis by GridCo of the total installed electricity capacity and total electricity demand reveals a supply deficit of about $9 \mathrm{GWh}$. The shortage is further compounded by transformer and feeder overloads which are blamed on the unrealistic tariffs charged by the utility companies and the failure of institutions and households to settle their electricity bills. The utility companies are thus constrained by the low tariffs to upgrade their systems to meet the increasing demand for electricity (Daily Graphic, 4/02/2010). Due to the poor electricity service delivery evident in the frequent and unannounced blackouts, the consuming population are not ready for increases in the tariffs. The ramifications are incessant blackouts which last for an average of 10.3 hours per month. Consequently, the researchers observed a $5.3 \%$ reduction in the quantity of electricity used by the MSI compared with what they needed for uninterrupted operations. About $44 \%$ of the MSI are rendered redundant due to lack of alternative sources of power during the blackout hours. These MSI however bear labour cost during blackout hours.

The researchers argue that the supply-side holds the key to reliable and adequate electricity supply in Ghana. The researchers maintain that the central government should augment the investments in the electricity subsector in order to generate and supply the required amount of electricity to address the interruptions in power, since reliable electricity is one of the key factors for ensuring sustained poverty reduction in a middle income economy like Ghana. Fewer interruptions in power supply could be a means to charging realistic tariffs as consumers may have value for the tariffs they pay. The researchers subsequently recommend the exploitation of the potential sources of electricity towards the diversification of Ghana's electricity generation-mix. The potential of 'small and mini hydro power' sites which are dispersed over 70 sites in Ghana (and capable of generating about $25 \mathrm{MW}$ ) could be explored to augment electricity supply in Ghana (Energy Commission, 2006). Furthermore, Ghana's wind resources (confined to the coastline and the Ghana-Togo border with favourable wind velocities of between $6-7 \mathrm{~m} / \mathrm{s}$ ) can be harnessed to supplement the electricity generation capacity (Akuffo, 2008).

The landfill potential can also be harnessed to augment electricity generation in Ghana. The daily waste of 1,200 tonnes generated in the Kumasi metropolis remains a potential for generating between 30 and $52 \mathrm{MW}$ (Ghana News Agency, 2007) of electricity to augment national electricity generation capacity. The two million tonnes of wood residues available in the country can also be harnessed for electricity generation. Most reliable data indicates that at least $95 \mathrm{MW}$ capacity capable of generating about $600 \mathrm{GWh}$ annually is expected to be tapped from farm-wastes, sawmills and logging residues (Energy Commission, 2006). The sawdust from the Sokoban Wood Village can be developed to provide electricity specifically for the industries located within the enclave. Akuffo (2008) also reveals that Ghana receives between 4-6 KWh per square metre of solar radiation per day which indicates a huge potential for the development of solar energy in Ghana. This potential can be harnessed for lighting purposes in remote rural areas in order to shed off the pressure on the national grid.

Institutions and households should be made to settle their electricity bills to enable the utility companies to deliver improved services. The enterprise owners should also be sensitised to see the need for eco-friendly and modern equipment for their operations. In conclusion, the researchers indicate that these recommendations are contingent upon political will complemented with careful and comprehensive feasibility studies to see them through. 


\section{References}

Adeya, N. (2006). Knowledge, Technology and Growth: The Case Study of Suame Manufacturing Enterprise Cluster in Ghana, Knowledge for Development (K4D) Programme. World Bank Institute, World Bank. [Online] Available:

http://siteresources.worldbank.org/KFDLP/Resources/4611971146505167962/Suame_Cluster_Ghana_revised_ April_2006.pdf (October 5, 2010)

Afful-Dadzie, A. (2009). Who is Who; Electricity or Telecommunication? Feature article in Modern Ghana News, 25 March $2009 . \quad$ [Online] Available: http://www.modernghana.com/news/207999/1/who-is-who-electricity-or-telecommunication.html (December 28, 2011)

Afronews. (2010). Energy prices to hit the sky in Ghana. [Online] Available: http://www.afrol.com/News2002/gha014_energy_prices.htm (October 5, 2010)

Akuffo, F. O. (2008). Ghana's Energy Resources Options: Issues for the Development and Utilisation of Renewable Energy Resources in Ghana. Energy and Ghana's Socio-economic Development, Development and Policy Dialogue Report One, George Benneh Foundation, Accra.

Amponsah, O. (2010). Towards a Reliable and Sustainable Supply of Electricity for Micro and Small Scale Industries in Kumasi. An unpublished Thesis submitted to the School of Graduate Studies, Kwame Nkrumah University of Science and Technology in partial fulfilment of the awards of a Master of Science Degree in Development Policy and Planning. (June, 2010).

Anderson, P. L., \& Geckil, I. K. (2003). Northeast Blackout Likely to Reduce US Earnings by \$6.4 Billion. Anderson Economic Group Working Paper 2003-2. [Online] Available: http://www.andersoneconomicgroup.com/Portals/0/upload/Doc544.pdf (December 29, 2011)

Ardayfio-Schandorf, E. (2009). Energy and the Development Nexus, the Realities, Challenges and Opportunities for the Future, an Inaugural Lecture Delivered at the University of Ghana on $16^{\text {th }}$ September, 2004, Accra, Ghana: University Press.

Aremu, M. A., \& Adeyemi, S. (2011). Small and Medium Scale Enterprises as a Survival Strategy for Employment Generation in Nigeria. Journal of Sustainable Development, 4 (1), 200 - 206. http://dx.doi.org/10.5539/jsd.v4n1p200

Association of Ghana Industries. (2009). AGI Policy Perspectives. Accra: Midland Press Limited.

AusAID. (2001). Power for the People: Renewable Energy in Developing Countries, A Summary of Discussion at the Renewable Energy Forum, Canberra, 18 October 2000, hosted by the Australian Agency for International Development (AusAID). [Online] Available: http://www.ausaid.gov.au/publications/pdf/renewable_energy.pdf (December 30, 2011)

Awotwi, K. A. (2011). Ghana's Energy Sector and Economic Outlook, a presentation at the Second Economic Lecture Series, Dei Centre.

Burlando, A. (2010). The Impact of Electricity on Work and Health: Evidence from a Blackout in Zanzibar. [Online]

Available:

http://www.google.com.gh/url?sa=t\&rct=j\&q=effects\%20of\%20blackouts\%20on\%20economic\%20activities\&s ource=web\&cd=2\&ved=0CCAQFjAB\&url=http $\% 3 \mathrm{~A} \% 2 \mathrm{~F} \% 2 \mathrm{~F}$ www.aeaweb.org\% $\% 2 \mathrm{Faea} \% 2 \mathrm{~F} 2011$ conference $\% 2$ Fprogram\%2Fretrieve.php\%3Fpdfid\%3D523\&ei=IIT8TuvMIomf-Qb_9IHdBQ\&usg=AFQjCNEVPHtX1duzA1 sK7-BKs47bQKdi4w\&cad=rja (December 12, 2011)

Centre for Policy Analysis. (2007). The Energy Crisis and Growth Performance of the Economy. Ghana Selected Economic Issues, CEPA Issue Paper No. 15. [Online] Available: http://www.cepa.org.gh/researchpapers/GSEI\%20No.\%2015\%202007\%20The\%20Energy\%20Crisis\%20and\%2 0Growth49.pdf (December 29, 2011)

Confederation of Tanzania Industries (CTI). (2011). Challenges of Unreliable Electricity Supply to Manufacturers in Tanzania, A Policy Research Paper Submitted to Energy Sector Stakeholders in Advocacy for Ensured Reliable Electricity Supply to Tanzanian Manufacturers, July 2011. [Online] Available: http://best-ac.org/site/REPORTS_files/CTI\%20Power\%20Report-\%20Executive\%20Summary\%20\%282011-08 \%29.pdf (December 29, 2011) 
Corwin, J. L., \& Miles, W. T. (1977). Impact Assessment of the 1977 New York City Blackout. A study commissioned by Electric Energy Systems (EES), Department of Energy (DOE). [Online] Available: http://blackout.gmu.edu/archive/pdf/impact_77.pdf (December 29, 2011)

Daily Graphic. (2009). Energy Sector Needs \$10bn to finance initiatives in next 5 years, Accra, No. 17896, Graphic Communications Group.

Daily Graphic. (2010). Energy Crisis looms as VRA crawls on dwindling income, Accra, No. 17896, Graphic Communications Group.

DFID. (2008). What's Stopping us Building a Global Society, how to bring international organisations into the 21 st century, in the Developments Journal, Issue No. 42. London, Engage Group (pp. 14 - 17).

Edjekumhene, I., Atokora, S. B., Atta-Konadu, R., \& Brew-Hammond, A. (2001). Implementation of Renewable Energy Technologies: Opportunities and Barriers, Ghana Country Study. UNEP Collaborating Centre on Energy and Environment, Roskilde. (pp. 146). [Online] Available: http://uneprisoe.org/RETs/GhanaCountryStudy.pdf (February 17, 2010)

Electricity Company of Ghana. (2011). State agencies urged to honour debts to ECG. [Online] Available: http://www.ecgonline.info/ecgweb/CurrentIssues/tabid/161/Default.aspx (November 30, 2011)

Energy Commission. (2006). Strategic National Energy Plan -206-2020, Main Report, July 2006. [Online] Available: http://new.energycom.gov.gh/pgs/reports.php (August 17, 2010)

Energy Commission. (2010). 2010 Energy, Supply and Demand Outlook for Ghana. [Online] Available: http://new.energycom.gov.gh/downloads/2010Energy_Outlook.pdf (August 16, 2011)

Energy Commission. (2011). Energy Commission calls for collaboration on ban of imported refrigerators, [Online]

Available:

http://www.ghanabusinessnews.com/2011/06/15/energy-commission-calls-for-collaboration-on-ban-of-imported -refrigerators/ (August 24, 2011)

Energy Sector Management Assistance Program (ESMAP). (2005). Ghana: Poverty and Social Impact Analysis of Electricity Tariffs. ESMAP Technical Paper 088. [Online] Available: http://www.esmap.org/esmap/sites/esmap.org/files/08805GhanaPSIKeenerForWeb.pdf (December 28, 2011)

Ghana National Commission for UNESCO (n.d). (2011). Energy, Oil and Gas; Powering the Nation. [Online] Available: http://www.natcomreport.com/ghana/livre/energy.pdf (August 21, 2011)

Ghana News Agency. (2007). Plant to re-cycle waste for Kumasi, [Online] Available: http://www.modernghana.com/news/66783/1/plant-to-re-cycle-waste-for-kumasi.html (December 28, 2011)

Ghana Web. (2010). Increases in electricity and water tariffs. [Online] Available: http://www.ghanaweb.com/GhanaHomePage/NewsArchive/artikel.php?ID=183154, Accra, May 31, GNA - The Public Utility Regulatory (September 5, 2010)

Government of Ghana. (2005). Growth and Poverty Reduction Strategy (2006 - 2009), Accra, National Development Planning Commission.

Gyau-Boakye, P., \& Tumbulto, J. W. (2001). Environmental Impacts of the Akosombo Dam and Effects of Climate Change on the Lake Levels. Journal of Environment, Development and Sustainability, 3 (1), 17-29. http://dx.doi.org/10.1023/A:1011402116047

Institute of Statistical, Social and Economic Research. (2005). The Guide to Electric Power, first edition, Resource Centre for Energy Economics and Regulation, University of Ghana, Legon - Accra.

Kadman, N. (2009). Red Lines Crossed: Destruction of Gaza's Infrastructure. [Online] Available: http://gisha.org/UserFiles/File/publications_/Infrastructures_Report_Aug09_Eng.pdf (December 30, 2011)

King, R. S. (2010). The Role of Urban Market Trade in Local Development Processes Implications for Policy, Saarbrücken, Germany, Lambert Academic Publishing.

Kumasi Metropolitan Assembly. (2010). Medium Term Development Plans, 2010 - 2013, unpublished development plan.

Malerba, F., \& Orsenigo, L. (1994). The Dynamic and Evolution of Industries, Working paper WP-94-120 in the International Institute for Applied System Analysis, Luxemberg - Austria.

Mensah, S. (2004). A Review of SME Financing Schemes in Ghana. A paper presented at the UNIDO Regional Workshop of Financing Small and Medium Scale Enterprises, Accra, Ghana. (March 15-16, 2004) 
Ministry of Energy. (2010). National Energy Policy. [Online] Available: http://ghanaoilwatch.org/images/laws/national_energy_policy.pdf (December 29, 2011)

Modern Ghana. (2010). Statement: ICU petition to government on utility tariffs. [Online] Available: http://www.modernghana.com/news/286735/1/statement-icu-petition-to-government-on-utility-ta.html (August 26, 2010)

Myjoyonline. (2010). Thousands demonstrate over high utility tariffs. [Online] Available: http://news.myjoyonline.com/news/201007/49896.asp (October 2, 2010)

National Development Planning Commission. (NDCP). (2008). Draft Long Term Development Plan, Vol. 1, Towards a Development Policy Framework, Unpublished.

Niasse, M. (2005). Climate-Induced Water Conflict Risks in West Africa: Recognising and Coping with Increasing Climate Impacts on Shared Watercourses. A presentation made at an International Workshop on the theme Human Security and Climate Change, Holmen Fjord Hotel, Asker, near Oslo, 21-23 June 2005.

Ofosu-Ahenkorah, A. K. (2008). Ghana's Energy Resource Options: Energy Conservation in Energy and Ghana's Socio-economic Development, Development and Policy Dialogue Report One, George Benneh Foundation, Accra (pp. 51 - 65).

Oviemuno, A. O. (2006). Impact of Energy on the Manufacturing Sector in Nigeria. [Online] Available: http://searchwarp.com/swa70577.htm (February 3, 2010)

Peters, R., Kesavan, M., \& Palmer, E. (2011). Clean Cool: The Next Iteration of Green Refrigeration. [Online] Available:

http://engineering.case.edu/desp/sites/engineering.case.edu.desp/files/Clean\%20Cool-Final\%20Report.pdf (December 30, 2011)

The Ghanaian Times. (2010). Listen to AGI and Employers. [Online] Available: http://www.newtimes.com.gh/story/listen-to-agi-and-employers (December 29, 2011)

Turkson, J. K., \& Amadu, M. B. (1999). Environmental Protection Implications of Electric Power Restructuring in Ghana, Riso National Laboratory, Rocklide, Denmark.

Velázquez, N. (2006). Impact of Rising Energy Costs on Small Business, Report by the House Small Business Committee, Congress of the United States, House of Representatives.

Table 1. The clusters of enterprises

\begin{tabular}{cccc}
\hline Type of Industry & Sample Frame & Sample Size & Number of Enterprise Owners Interviewed \\
\hline Wood Processing & 4,000 & 66 & 66 \\
Cold Stores & 400 & 58 & 58 \\
Sachet Water Production & 362 & 57 & 57 \\
Dressmaking & 93 & 39 & 39 \\
Grinding Mills & 70 & 35 & 35 \\
Printing Presses & 50 & 29 & 29 \\
Sprayers & n.a. & 18 & 18 \\
Straighters \& Welders & n.a. & 18 & 18 \\
\hline Total & - & 320 & 320
\end{tabular}

Source: Field Survey, 2010 
Table 2. Ghana's total electricity installed capacity as of 2009

\begin{tabular}{|c|c|c|c|}
\hline Source of Power & Type & $\begin{array}{l}\text { Installed Capacity } \\
\text { (MW) }\end{array}$ & $\begin{array}{l}\text { Actual Energy Supplied } \\
\text { (GWh) }\end{array}$ \\
\hline $\begin{array}{l}\text { Akosombo hydro generating station (6 X } \\
160 \mathrm{MW} \text { units) }\end{array}$ & Hydro & 1,020 & 5,841 \\
\hline $\begin{array}{l}\text { Kpong hydro generating station (4 X } 40 \\
\text { MW units) }\end{array}$ & Hydro & 160 & 1,035 \\
\hline $\begin{array}{l}\text { Takoradi Thermal Plant Station (TAPCO): } \\
\qquad \begin{array}{c}\text { (GT) } 2 \text { X } 110 \mathrm{MW} \\
\text { (CCT) } 1 \text { X } 110 \mathrm{MW}\end{array}\end{array}$ & $\begin{array}{l}\text { Combined } \\
\text { cycle } \\
\text { Thermal }\end{array}$ & $\begin{array}{l}220 \\
110\end{array}$ & 453 \\
\hline $\begin{array}{l}\text { Takoradi Thermal International Company } \\
\text { (TICO): GT) } 2 \text { X } 110 \mathrm{MW}\end{array}$ & $\begin{array}{l}\text { Single cycle } \\
\text { Thermal }\end{array}$ & 220 & 1,040 \\
\hline Mines Reserve Plant & Thermal & 80 & 18 \\
\hline $\begin{array}{l}\text { Tema } 1 \text { Thermal Plant } \\
\text { (Currently in commercial operation) }\end{array}$ & Thermal & 120 & 570 \\
\hline Total Installed Capacity & & 1,930 & 8,957 \\
\hline
\end{tabular}

Source: Awotwi, 2011; p. 9

Table 3. Total electricity demand 2008 - 2010

\begin{tabular}{cccc}
\hline $\begin{array}{c}\text { Generation requirements } \\
(\mathrm{GWh})\end{array}$ & $\begin{array}{c}\text { Generation Capacity } \\
(\mathrm{GWh})\end{array}$ & Potential Shortfall & Forecasting Agency \\
\hline $8,500-12,500$ & $9,000-10,600$ & $\leq 2,700$ & Energy Commission \\
10,116 & 9,800 & 316 & GridCo \\
\hline
\end{tabular}

Adopted from Energy Commission, 2010, p: 7.

Table 4. MSI monthly electricity consumption levels and tariffs paid

\begin{tabular}{|c|c|c|c|c|c|c|c|}
\hline \multirow[b]{2}{*}{ Firms } & \multirow[b]{2}{*}{$\begin{array}{l}\text { Kilowatts } \\
\text { hour of } \\
\text { electricity } \\
\text { per month }\end{array}$} & \multicolumn{6}{|c|}{ Monthly Tariffs } \\
\hline & & $\begin{array}{l}\text { Amount } \\
\text { required to } \\
\text { pay (without } \\
\text { subsidy) } \\
(\mathrm{GH} \phi))\end{array}$ & $\begin{array}{l}\text { Amount paid } \\
\text { (i.e. } \\
\text { subsidised) }\end{array}$ & $\begin{array}{c}\text { Service } \\
\text { Charges } \\
(\mathrm{GH} \phi)\end{array}$ & $\begin{array}{c}\text { VAT \& } \\
\text { NHIL } \\
@ \\
15 \%\end{array}$ & $\begin{array}{l}\text { Total } \\
(\mathrm{GH} \phi)\end{array}$ & $\begin{array}{c}\text { Subsidy } \\
\text { effect on } \\
\text { the tariff } \\
(\%)\end{array}$ \\
\hline Cold Store & 936.5 & 207 & 149.8 & 2.5 & 22.47 & 174.8 & 18.4 \\
\hline Printing Presses & 740.2 & 164 & 111.4 & 2.5 & 16.71 & 130.6 & 25.6 \\
\hline $\begin{array}{c}\text { Wood } \\
\text { Processing }\end{array}$ & 650.2 & 145 & 93.6 & 2.5 & 14.04 & 110.1 & 31.7 \\
\hline $\begin{array}{l}\text { Straightening \& } \\
\text { Welding }\end{array}$ & 555.9 & 105 & 77.4 & 2.5 & 11.61 & 91.5 & 14.8 \\
\hline Sachet Water & 545.5 & 103 & 72.1 & 2.5 & 10.815 & 85.4 & 20.6 \\
\hline Grinding Mills & 337.6 & 49 & 39.8 & 2.5 & 5.97 & 48.2 & 1.7 \\
\hline Spraying & 283.8 & 42 & 29.5 & 2.5 & 4.425 & 36.4 & 15.4 \\
\hline Dressmaking & 247.3 & 37 & 24.1 & 2.5 & 3.615 & 30.2 & 22.5 \\
\hline
\end{tabular}

Source: Filed Survey, May, 2010 
Table 5. The MSI estimated daily electricity consumption

\begin{tabular}{cccccc}
\hline Firms & $\begin{array}{c}\text { KWh per } \\
\text { Month A }\end{array}$ & $\begin{array}{c}\text { Mean Daily Hours } \\
\text { of Work B }\end{array}$ & $\begin{array}{c}\text { Mean Working } \\
\text { Days por Month } \\
\text { C }\end{array}$ & $\begin{array}{c}\text { Mean Working } \\
\text { Hours per } \\
\text { Month } \\
\mathrm{D}=(\mathrm{B} * \mathrm{C})\end{array}$ & $\begin{array}{c}\text { Hourly } \\
\text { Electricity } \\
\text { Consumption } \\
\mathrm{E}=(\mathrm{A} \div \mathrm{D})\end{array}$ \\
\hline $\begin{array}{c}\text { Printing Presses } \\
\text { Cold Store }\end{array}$ & 740.2 & 7.7 & 26 & 200.2 & 3.7 \\
$\begin{array}{c}\text { Wood } \\
\text { Processing }\end{array}$ & 936.5 & 24 & 30 & 720 & 1.3 \\
Sachet Water & 540.2 & 10 & 26 & 260 & 2.5 \\
Straightening & 555.5 & 6.2 & 26 & 161.2 & 3.4 \\
and Welding & 53.9 & 6 & 26 & 156 & 3.6 \\
Grinding Mills & 337.6 & 10 & 26 & 260 & 1.3 \\
Spraying & 283.8 & 5.5 & 26 & 143 & 2.0 \\
Dressmaking & 247.3 & 5.4 & 26 & 140.4 & 1.8 \\
\hline
\end{tabular}

Source: Field Survey, May 2010

Table 6. Duration of interrupted power supply

\begin{tabular}{ccc}
\hline Firms & Blackout hours per week & Blackout hours per month \\
\hline Printing Presses & 2.5 & 10.0 \\
Cold Store & 2.7 & 10.8 \\
Wood Processing & 2.0 & 8.0 \\
Sachet Water & 2.6 & 10.4 \\
Straightening and Welding & 3.0 & 12.0 \\
Grinding Mills & 2.8 & 11.2 \\
Spraying & 3.0 & 12.0 \\
Dressmaking & 2.0 & 8.0 \\
Average & 2.6 & 10.3 \\
\hline
\end{tabular}

Source: Field Survey, May 2010 
Table 7. The MSI actual electricity requirement

\begin{tabular}{|c|c|c|c|c|c|c|}
\hline Firms & $\begin{array}{l}\text { Actual KWh } \\
\text { supplied to } \\
\text { the MSI per } \\
\text { Month } \\
\text { A }\end{array}$ & $\begin{array}{c}\text { Blackout } \\
\text { Hours per } \\
\text { Month } \\
\text { B }\end{array}$ & $\begin{array}{l}\text { Electricity } \\
\text { Consumption } \\
\text { per Hour of } \\
\text { Work } \\
\text { (in KWh) } \\
\text { C }\end{array}$ & $\begin{array}{l}\text { Additional } \\
\text { Electricity } \\
\text { Required per } \\
\text { Month for } \\
\text { Continuous } \\
\text { Operations } \\
\text { (in KWh) } \\
\mathrm{D}=(\mathrm{B} * \mathrm{C})\end{array}$ & $\begin{array}{c}\text { Total } \\
\text { Electricity } \\
\text { Requirement } \\
\text { for } \\
\text { Uninterrupted } \\
\text { Operations } \\
\mathrm{E}=(\mathrm{A}+\mathrm{D})\end{array}$ & $\begin{array}{l}\text { Difference } \\
\text { between } \\
\text { actual and } \\
\text { required } \\
\text { amounts of } \\
\text { electricity } \\
(\%) \\
\text { A-E }\end{array}$ \\
\hline Printing Presses & 740.2 & 10.0 & 3.7 & 37.0 & 777.2 & 5.0 \\
\hline Cold Store & 936.5 & 10.8 & 1.3 & 14.0 & 950.5 & 1.5 \\
\hline $\begin{array}{c}\text { Wood } \\
\text { Processing }\end{array}$ & 650.2 & 8.0 & 2.5 & 20.0 & 670.2 & 3.1 \\
\hline Sachet Water & 545.5 & 10.4 & 3.4 & 35.4 & 580.9 & 6.5 \\
\hline $\begin{array}{l}\text { Straightening } \\
\text { and Welding }\end{array}$ & 555.9 & 12.0 & 3.6 & 43.2 & 599.1 & 7.8 \\
\hline Grinding Mills & 337.6 & 11.2 & 1.3 & 14.6 & 352.2 & 4.3 \\
\hline Spraying & 283.8 & 12.0 & 2.0 & 24.0 & 307.8 & 8.5 \\
\hline Dressmaking & 247.3 & 8.0 & 1.8 & 14.4 & 261.7 & 5.8 \\
\hline Average & - & 10.2 & - & - & - & 5.3 \\
\hline
\end{tabular}

Source: Field Survey, May 2010

Table 8 . Alternatives used by the entrepreneurs during blackouts

\begin{tabular}{|c|c|c|c|c|c|c|c|c|}
\hline \multirow{3}{*}{ firms } & \multicolumn{6}{|c|}{ alternatives used } & \multirow{2}{*}{\multicolumn{2}{|c|}{ total }} \\
\hline & \multicolumn{2}{|c|}{ none } & \multicolumn{2}{|c|}{ Lpg } & \multicolumn{2}{|c|}{$\begin{array}{l}\text { petrol powered } \\
\text { generators }\end{array}$} & & \\
\hline & $\mathrm{n}$ & $\%$ & $\mathrm{n}$ & $\%$ & $\mathrm{n}$ & $\%$ & $\mathrm{n}$ & $\%$ \\
\hline $\begin{array}{l}\text { straightening and } \\
\text { welding }\end{array}$ & 8 & 44.4 & 10 & 55.6 & 0 & 0.0 & 18 & 100.0 \\
\hline spraying & 18 & 100.0 & 0 & 0.0 & 0 & 0.0 & 18 & 100.0 \\
\hline $\begin{array}{l}\text { sachet water } \\
\text { manufacturing }\end{array}$ & 17 & 29.8 & 0 & 0.0 & 40 & 71.2 & 57 & 100.0 \\
\hline cold stores & 0 & 0.0 & 0 & 0.0 & 58 & 100.0 & 58 & 100.0 \\
\hline wood processors & 66 & 100.0 & 0 & 0.0 & 0 & 0.0 & 66 & 100.0 \\
\hline grinding mills & 35 & 100.0 & 0 & 0.0 & 0 & 0.0 & 35 & 100.0 \\
\hline printing presses & 0 & 0.0 & 0 & 0.0 & 30 & 100.0 & 30 & 100.0 \\
\hline dressmaking & 45 & 77.6 & 0 & 0.0 & 13 & 22.4 & 58 & 100.0 \\
\hline
\end{tabular}

Source: Field Survey, May 2010 


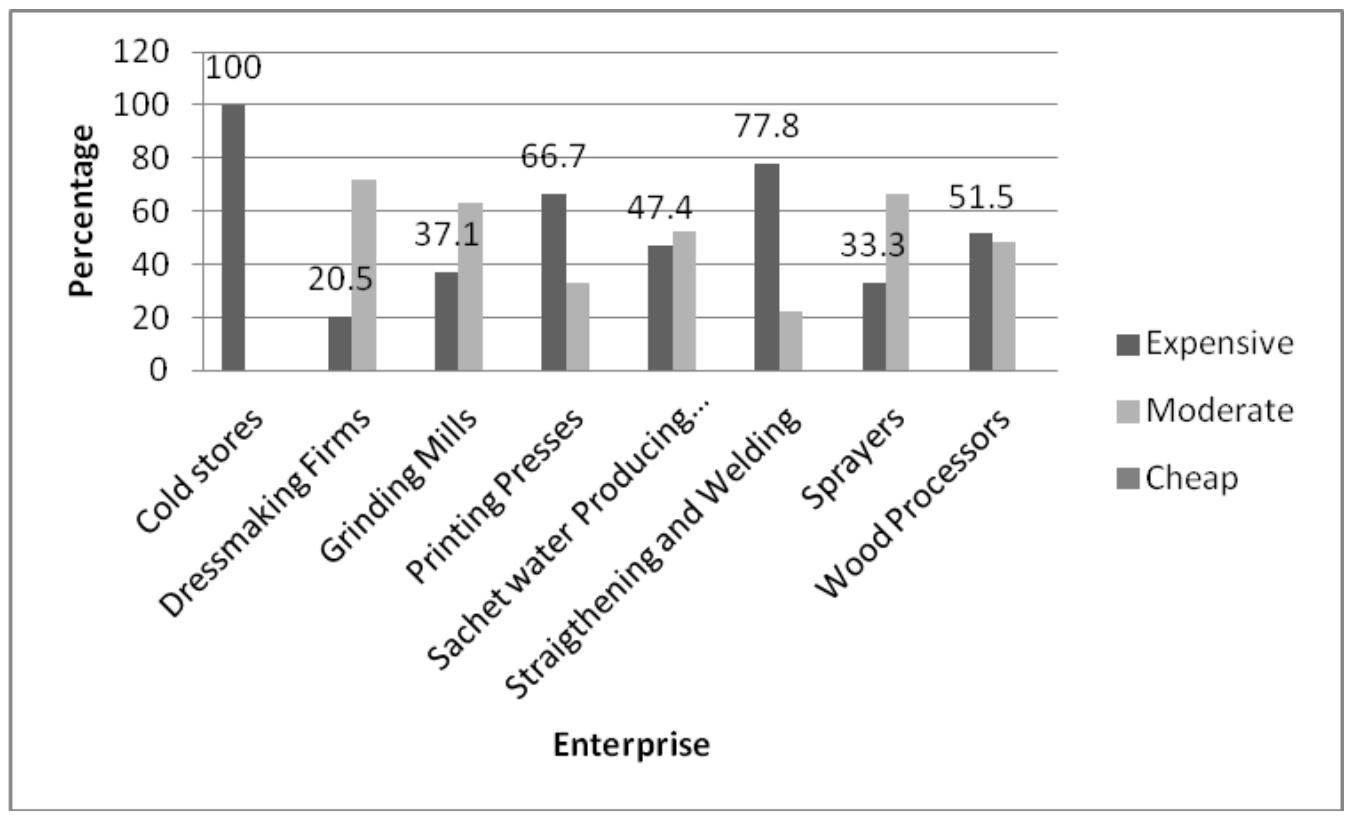

Figure 1. Entrepreneurs' perception about electricity tariffs 
Appendix 1. Estimating the quantity of electricity consumed by the enterprises and the associated bills

\begin{tabular}{cccccc}
\hline Units $(\mathrm{KWh})$ & Number & Percent & Tariff $(\mathrm{GH} \phi)$ & Number & Percent \\
\hline Cold store & & 0.0 & & & 0.0 \\
$0-50$ & 0 & 0.0 & $0-4.75$ & 0 & 0.0 \\
$51-300$ & 0 & 0.0 & $3.7-21.6$ & 0 & 0.0 \\
$301-600$ & 0 & 0.0 & $28.96-76.80$ & 0 & 0.0 \\
$601-900$ & 22 & 37.9 & $86.0-142.8$ & 22 & 37.9 \\
$901+$ & 36 & 62.1 & $143+$ & 36 & 62.1 \\
Total & 58 & 100.00 & & 58 & 100 \\
Mean =936.5 & & & Mean $=149.80$ & &
\end{tabular}

Dressmakers

$\begin{array}{cccccc}0-50 & 0 & 0.0 & 0-4.75 & 0 & 0.0 \\ 51-300 & 31 & 79.5 & 3.7-21.6 & 31 & 79.5 \\ 301-600 & 6 & 15.4 & 28.96-76.80 & 6 & 15.4 \\ 601-900 & 2 & 5.1 & 86.0-142.8 & 2 & 5.1 \\ 901+ & 0 & 0.0 & 143+ & 0 & 0.0 \\ \text { Total } & 30 & 100 & & 39 & 100\end{array}$

Mean $=247.3 \quad$ Mean $=24.1$

\begin{tabular}{|c|c|c|c|c|c|}
\hline \multicolumn{6}{|l|}{ Grinding Mills } \\
\hline $0-50$ & 0 & 0.0 & $0-4.75$ & 0 & 0.0 \\
\hline $51-300$ & 22 & 62.9 & $3.7-21.6$ & 31 & 79.5 \\
\hline $301-600$ & 7 & 20.0 & $28.96-76.80$ & 6 & 15.4 \\
\hline $601-900$ & 5 & 14.3 & $86.0-142.8$ & 2 & 5.1 \\
\hline $901+$ & 1 & 2.9 & $143+$ & 0 & 0.0 \\
\hline Total & 35 & 100.0 & & 30 & 100 \\
\hline Mean $=247.3$ & & & Mean $=39.80$ & & \\
\hline \multicolumn{6}{|l|}{ Printing press } \\
\hline $0-50$ & 0 & 0.0 & $0-4.75$ & 0 & 0.0 \\
\hline $51-300$ & 0 & 0.0 & $3.7-21.6$ & 0 & 0.0 \\
\hline $301-600$ & 7 & 23.3 & $28.96-76.80$ & 7 & 23.3 \\
\hline $601-900$ & 17 & 56.7 & $86.0-142.8$ & 17 & 56.7 \\
\hline $901+$ & 6 & 20.0 & $143+$ & 6 & 20.0 \\
\hline Total & 30 & 100.0 & & 30 & 100.0 \\
\hline Mean $=740.2$ & & & Mean $=111.4$ & & \\
\hline \multicolumn{6}{|l|}{ Sachet water } \\
\hline $0-50$ & 0 & 0.0 & $0-4.75$ & 0 & 0.0 \\
\hline $51-300$ & 0 & 0.0 & $3.7-21.6$ & 0 & 0.0 \\
\hline $301-600$ & 41 & 71.9 & $28.96-76.80$ & 41 & 71.9 \\
\hline $601-900$ & 14 & 24.6 & $86.0-142.8$ & 14 & 24.6 \\
\hline $901+$ & 2 & 3.5 & $143+$ & 2 & 3.5 \\
\hline Total & 57 & 100.0 & & 57 & 100.0 \\
\hline Mean $=545.1$ & & & Mean $=72.1$ & & \\
\hline
\end{tabular}


Appendix 1. Estimating the quantity of electricity consumed by the enterprises and the associated bills (continued)

\begin{tabular}{|c|c|c|c|c|c|}
\hline Units (KWh) & Number & Percent & Tariff $(\mathrm{GH} \phi)$ & Number & Percent \\
\hline \multicolumn{6}{|c|}{ Straightening and welding } \\
\hline $0-50$ & 0 & 0.0 & $0-4.75$ & 0 & 0.0 \\
\hline $51-300$ & 4 & 22.2 & $3.7-21.6$ & 4 & 22.2 \\
\hline $301-600$ & 7 & 38.9 & $28.96-76.80$ & 7 & 38.9 \\
\hline $601-900$ & 4 & 22.2 & $86.0-142.8$ & 4 & 22.2 \\
\hline $901+$ & 3 & 16.7 & $143+$ & 3 & 16.7 \\
\hline Total & 18 & 100.0 & & 18 & 100.0 \\
\hline Mean $=555.9$ & \multicolumn{5}{|c|}{ Mean $=77.4$} \\
\hline \multicolumn{6}{|l|}{ Sprayers } \\
\hline $0-50$ & 0 & 0.0 & $0-4.75$ & 0 & 0.0 \\
\hline $51-300$ & 12 & 66.7 & $3.7-21.6$ & 12 & 66.7 \\
\hline $301-600$ & 5 & 27.8 & $28.96-76.80$ & 5 & 27.8 \\
\hline $601-900$ & 1 & 5.6 & $86.0-142.8$ & 1 & 5.6 \\
\hline $901+$ & 0 & 0.0 & $143+$ & 0 & 0.0 \\
\hline Total & 18 & 100.0 & & 18 & 100.0 \\
\hline Mean $=283.8$ & \multicolumn{5}{|c|}{ Mean $=29.5$} \\
\hline \multicolumn{6}{|l|}{$\begin{array}{c}\text { Wood } \\
\text { processors }\end{array}$} \\
\hline $0-50$ & 0 & 0.0 & $0-4.75$ & 0 & 0.0 \\
\hline $51-300$ & 0 & 0.0 & $3.7-21.6$ & 0 & 0.0 \\
\hline $301-600$ & 26 & 39.4 & $28.96-76.80$ & 26 & 39.4 \\
\hline $601-900$ & 36 & 54.5 & $86.0-142.8$ & 36 & 54.5 \\
\hline $901+$ & 4 & 6.1 & $143+$ & 4 & 6.1 \\
\hline Total & 66 & 100.0 & & 66 & 100.0 \\
\hline Mean $=650.2$ & & & Mean $=93.6$ & & \\
\hline
\end{tabular}

Source: Field Survey, May, 2010 
Appendix 2. Cross-tabulating perception with tariffs paid by the enterprises

\begin{tabular}{|c|c|c|c|c|c|c|c|c|c|c|c|c|}
\hline \multirow{3}{*}{$\begin{array}{c}\text { Perceptions } \\
\begin{array}{l}\text { Straightening and } \\
\text { Welding }\end{array}\end{array}$} & \multicolumn{10}{|c|}{ Amount (measured in KWh) of Electricity Consumed } & \multirow{2}{*}{\multicolumn{2}{|c|}{ Total }} \\
\hline & \multicolumn{2}{|c|}{$0-50$} & \multicolumn{2}{|c|}{$51-300$} & \multicolumn{2}{|c|}{$301-600$} & \multicolumn{2}{|c|}{$601-900$} & \multicolumn{2}{|c|}{$901+$} & & \\
\hline & $\mathrm{N}$ & $\%$ & $\mathrm{~N}$ & $\%$ & $\mathrm{~N}$ & $\%$ & $\mathrm{~N}$ & $\%$ & $\mathrm{~N}$ & $\%$ & $\mathrm{~N}$ & $\%$ \\
\hline Expensive & 0 & 0 & 0 & 0.0 & 7 & 38.9 & 4 & 22.2 & 3 & 16.7 & 14 & 77.8 \\
\hline Moderate & 0 & 0 & 4 & 22.2 & 0 & 0.0 & 0 & 0.0 & 0 & 0.0 & 4 & 22.2 \\
\hline Cheap & 0 & 0 & 0 & 0.0 & 0 & 0.0 & 0 & 0.0 & 0 & 0.0 & 0 & 0.0 \\
\hline Total & 0 & 0 & 4 & 22.2 & 7 & 38.9 & 4 & 22.2 & 3 & 16.7 & 18 & 100.0 \\
\hline \multicolumn{13}{|l|}{ Spraying Firms } \\
\hline Expensive & 0 & 0 & 0 & 0.0 & 5 & 27.8 & 1 & 5.6 & 0 & 0 & 6 & 33.3 \\
\hline Moderate & 0 & 0 & 12 & 66.7 & 0 & 0.0 & 0 & 0 & 0 & 0 & 12 & 66.7 \\
\hline Cheap & 0 & 0 & 0 & 0.0 & 0 & 0.0 & 0 & 0 & 0 & 0 & 0 & 0.0 \\
\hline Total & 0 & 0 & 12 & 66.7 & 5 & 27.8 & 1 & 5.6 & 0 & 0 & 18 & 100.0 \\
\hline \multicolumn{13}{|l|}{ Sachet Water } \\
\hline \multicolumn{13}{|l|}{ Producing Firms } \\
\hline Expensive & 0 & 0 & 0 & 0 & 11 & 19.3 & 14 & 24.6 & 2 & 3.5 & 27 & 47.4 \\
\hline Moderate & 0 & 0 & 0 & 0 & 30 & 52.6 & 0 & 0.0 & 0 & 0.0 & 30 & 52.6 \\
\hline Cheap & 0 & 0 & 0 & 0 & 0 & 0.0 & 0 & 0.0 & 0 & 0.0 & 0 & 0.0 \\
\hline Total & 0 & 0 & 0 & 0 & 41 & 71.9 & 14 & 24.6 & 2 & 3.5 & 57 & 100.0 \\
\hline \multicolumn{13}{|l|}{ Cold Stores } \\
\hline Expensive & 0 & 0 & 0 & 0 & 0 & 0 & 11 & 19.0 & 47 & 81.0 & 58 & 100.0 \\
\hline Moderate & 0 & 0 & 0 & 0 & 0 & 0 & 0 & 0.0 & 0 & 0 & 0 & 0.0 \\
\hline Cheap & 0 & 0 & 0 & 0 & 0 & 0 & 0 & 0.0 & 0 & 0.0 & 0 & 0.0 \\
\hline Total & 0 & 0 & 0 & 0 & 0 & 0 & 11 & 19.0 & 47 & 81.0 & 58 & 100.0 \\
\hline \multicolumn{13}{|l|}{ Wood Processors } \\
\hline Expensive & 0 & 0 & 0 & 0 & 0 & 0.0 & 30 & 45.5 & 4 & 6.1 & 34 & 51.5 \\
\hline Moderate & 0 & 0 & 0 & 0 & 26 & 39.4 & 6 & 9.1 & 0 & 0.0 & 32 & 48.5 \\
\hline Cheap & 0 & 0 & 0 & 0 & 0 & 0.0 & 0 & 0.0 & 0 & 0.0 & 0 & 0.0 \\
\hline Total & 0 & 0 & 0 & 0 & 26 & 39.4 & 36 & 54.5 & 4 & 6.1 & 66 & 100.0 \\
\hline \multicolumn{13}{|l|}{ Grinding Mills } \\
\hline Expensive & 0 & 0 & 0 & 0.0 & 13 & 37.1 & 0 & 0 & 0 & 0 & 13 & 37.1 \\
\hline Moderate & 0 & 0 & 22 & 62.9 & 0 & 0.0 & 0 & 0 & 0 & 0 & 22 & 62.9 \\
\hline Cheap & 0 & 0 & 0 & 0.0 & 0 & 0.0 & 0 & 0 & 0 & 0 & 0 & 0.0 \\
\hline Total & 0 & 0 & 22 & 62.9 & 13 & 37.1 & 0 & 0 & 0 & 0 & 35 & 100.0 \\
\hline \multicolumn{13}{|l|}{ Printing Presses } \\
\hline Expensive & 0 & 0 & 0 & 0 & 1 & 3.3 & 15 & 50.0 & 4 & 13.3 & 20 & 66.7 \\
\hline Moderate & 0 & 0 & 0 & 0 & 6 & 20.0 & 2 & 6.7 & 2 & 6.7 & 10 & 33.3 \\
\hline Cheap & 0 & 0 & 0 & 0 & 0 & 0.0 & 0 & 0.0 & 0 & 0.0 & 0 & 0.0 \\
\hline Total & 0 & 0 & 0 & 0 & 7 & 23.3 & 17 & 56.7 & 6 & 20 & 30 & 100.0 \\
\hline \multicolumn{13}{|l|}{ Dressmaking firms } \\
\hline Expensive & 0 & 0 & 0 & 0.0 & 8 & 20.5 & 0 & 0 & 0 & 0 & 8 & 20.5 \\
\hline Moderate & 0 & 0 & 28 & 71.8 & 0 & 0 & 0 & 0 & 0 & 0 & 28 & 71.8 \\
\hline Cheap & 0 & 0 & 3 & 7.7 & 0 & 0 & 0 & 0 & 0 & 0 & 3 & 7.7 \\
\hline Total & 0 & 0 & 31 & 79.5 & 8 & 20.5 & 0 & 0 & 0 & 0 & 39 & 100.0 \\
\hline
\end{tabular}

Source: Field Survey, May, 2010

$* \mathrm{~N}=$ Number of enterprise owners 